\title{
Effects of Intercropping on Rhizosphere Soil Bacterial Communities in Amorphophallus konjac
}

\author{
Jinping $\mathrm{Wu}^{1,2}$, Zhenbiao Jiao², Jie Zhou², Wei Zhang3, Shengwu Xu4 ${ }^{4}$ Fengling Guo ${ }^{2 *}$ \\ ${ }^{1}$ Key Laboratory of Fertilizer Resource Utilization in Wastes, Ministry of Agriculture, Wuhan, China \\ ${ }^{2}$ Hubei Academy of Agricultural Sciences, Wuhan, China \\ ${ }^{3}$ Tongling City Agriculture Committee, Tongling, China \\ ${ }^{4}$ Xianning Academy of Agricultural Sciences, Xianning, China \\ Email: ^274184394@qq.com
}

How to cite this paper: Wu, J.P., Jiao, Z.B., Zhou, J., Zhang, W., Xu, S.W. and Guo, F.L. (2018) Effects of Intercropping on Rhizosphere Soil Bacterial Communities in Amorphophallus konjac. Open Journal of Soil Science, 8, 225-239. https://doi.org/10.4236/ojss.2018.89018

Received: July 19, 2018

Accepted: September 1, 2018

Published: September 4, 2018

Copyright (c) 2018 by authors and Scientific Research Publishing Inc. This work is licensed under the Creative Commons Attribution International License (CC BY 4.0).

http://creativecommons.org/licenses/by/4.0/

\section{(c) (i) Open Access}

\begin{abstract}
Soft rot disease causes heavy loss in konjac production every year, which caused by the genus Pectobacterium has been recognized as a major reason why konjac industry has not boomed in worldwide. However, intercropping with economically important trees can effectively control affect soft rot disease epidemics. Consequently, we conducted a rhizosphere bacterial diversity study to assess how intercropping affects soft rot disease using next-generation DNA sequencing. The results demonstrate the Shannon diversity index and Chao 1 index for soil bacteria were relatively steady under intercropping conditions, but changed greatly for the konjac monocrop with the increase in the number of cropping years. Of the 44 bacterial genera with relative abundance ratios of $>0.3 \%, 11$ were significantly affected by the duration of continuous cropping and the cultivation mode. Luteolibacter and Bacteroides showed highly significant differences between the monocrop and the intercrop for three continuous years. Pseudomonas was significantly affected by the different cultivation modes, while Myroides was significantly affected by planting age. Intercropping altered the structure and composition of the soil bacterial community, which led to a relative balance of beneficial bacteria, and the relative balance of beneficial bacteria is helpful to reduce the incidence of soft rot.
\end{abstract}

\section{Keywords}

Amorphophallus konjac, Soft Rot Disease, Bacterial Community, Intercropping

\section{Introduction}

Amorphophallus konjac K. Koch (Araceae) is mainly distributed throughout 
Southeast Asia and Africa [1]. A. konjac is a highly valued economic crop that is widely used in medicine, food, and the chemical industry. With the increasing demand for konjac products, intensive field planting of konjac is becoming more and more common. Konjac is indigenous to tropical rain forests, and it therefore grows well in shady environments [2]. Changes in the growth environment can result in serious bacterial soft rot diseases for konjac in the field, and the incidence of soft rot often exceeds $80 \%$ after three years of continuous cropping in the field [3]. Bacterial soft rot in konjac caused by the genus Pectobacterium has been recognized as a major reason why konjac industry has not boomed. The pathogen causes maceration and rotting of parenchymatous tissue of konjact organs, eventually resulting in plant death. Taking the grove-konjac intercropping mode, the original ecological planting has been realized for konjac [4]. Comparative studies on the disease incidence and yield of konjac in different types of forest land have been performed [4] [5], showing that the incidence of soft rot disease was low and the yields were high. For example, the average yield of konjac increased by $71.9 \%$ under acacia forest compared to farmland [6]. But at present, the mechanism underlying the health and high yield of konjac under the grove-konjac intercropping model is poorly understood, which limits the wide application of this model.

It is well known that the growth of crops is closely related to soil quality [7] [8]. Soil bacterial communities are sensitive indicators that are used for the assessment of soil quality. At present, high throughput DNA sequencing (such as that performed on the Illumina MiSeq instrument) has been recognized as a powerful tool to study bacterial communities, and amplification with specific PCR primers can effectively provide an insight into the diversity of bacterial groups at a fine scale [9] [10].

The relative health and yield of konjac were determined by the health status of the soil around the corm and its root system [11]. Thus, a systematic study on the differences in the rhizosphere bacteria was carried out under grove-konjac intercropping conditions using high throughput DNA sequencing on an Illumina MiSeq instrument to further explore the potential relationships between bacteria processes and soil bacteria. The previous methods were referenced in the analysis process [12]. Furthermore, it was our objective to develop strategies for the continuous cropping of konjac that improve soil function and quality for future cultivation.

\section{Material and Methods}

\subsection{Site Description and Experimental Design}

The experiments were carried out in Quanxi village, Shiyan city, Hubei province, China (B: $31^{\circ} 58.734^{\prime} \mathrm{N}, 109^{\circ} 40.213^{\prime} \mathrm{E} ; 1103 \mathrm{~m}$ ). This region has a typical subtropical monsoon climate with an average annual precipitation of $1000 \mathrm{~mm}$ and an average temperature of $14^{\circ} \mathrm{C}$. The soils are loam. The farmland was planted with corn (Zea mays L.) and the grove was planted with sumac (Tox- 
icodendron vernicifluum) until it was three years old. The field contained four plots $(5.0 \mathrm{~m} \times 10.0 \mathrm{~m})$ each in the farmland and grove, and each plot was repeated 3 times. Starting in 2013, konjac (Amorphophallus konjac K. Koch ex N.E. Br.) was cultivated each year in the field, and the study was completed in 2015.

Each growth cycle of the present study was initiated on or about April 5 with a few days of variation among years (Figure 1). Konjac corms (about $200 \mathrm{~g}$ ) were buried on the top of raised paths $(25 \mathrm{~cm}$ in height, $120 \mathrm{~cm}$ in width) and plants were spaced $30 \mathrm{~cm}$ apart along the row. Two rows were planted on each raised path with $40 \mathrm{~cm}$ between the two rows. The blended fertilizer with a ratio of 15:15:15 $\left(\mathrm{NH}_{4}\right)_{2} \mathrm{SO}_{4}: \mathrm{P}_{2} \mathrm{O}_{5}: \mathrm{K}_{2} \mathrm{O}$ was used for $750 \mathrm{~kg} \cdot \mathrm{ha}^{-1}$ in basal-dressing and 75 $\mathrm{kg} \cdot \mathrm{ha}^{-1}$ in top-dressing. All other field management activities were performed manually. Konjac corms were harvested in late October. The operation in the second year was repeated in the first year, and so on.

\subsection{Sample Collection and Preparation}

Rhizosphere samples were numbered as follows: F0 (cultivated corn for 3 years in farmland); F1 (cultivated corn for 2 years and konjac for 1 year in farmland); F2 (cultivated corn for 1 years and konjac for 2 years in farmland); F3 (cultivated konjac for 3 years in farmland); G0 (cultivated sumac grown for 6 years); G1 (cultivated konjac grown for 1 year under 4-year-old sumac); G2 (cultivated konjac for 2 years under 5-year-old sumac); G3 (cultivated konjac for 3 years under 6-year-old sumac).

Soil samples were collected on July 20, 2015. In each plot, soil was collected at four diagonal points using a sterile plastic bag and combined into a single sample. Every point is randomly selected 8 healthy konjacs in addition to the blank control (F0 and G0), rhizosphere samples were collected by the root-shaking method [13]. Soil samples of F0 and G0 were obtained at a depth of $5-25 \mathrm{~cm}$. The fresh soil samples were sieved through $2 \mathrm{~mm}$ mesh. The bulk soil samples were stored at $4^{\circ} \mathrm{C}$ for physical and chemical characterization [12], while the rhizosphere samples were stored at $-70^{\circ} \mathrm{C}$ prior to DNA extraction [14].

\subsection{Disease Incidence Statistics}

Konjac plants were collected and assessed for the presence and severity of plant disease. Disease incidence statistics included 100 plants from each soil sample. Soft rot symptoms of the leaves and petioles were identified in infected plants [15].

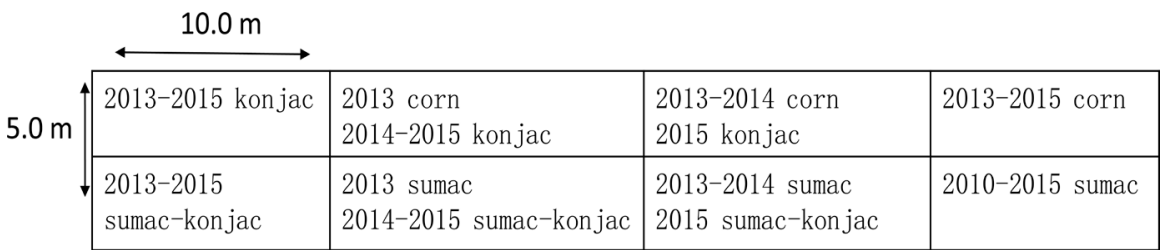

Figure 1. Field layout of the randomized cropping design used in the soil sampling experiments. 
Disease Incidence (DI) was calculated using the following formula:

$$
\text { DI }=\frac{\text { The number of infected plants }}{\text { Total number of plants investigated }} \times 100 \%
$$

\section{Bacterial community DNA sequencing}

Soil microbial DNA was isolated using the E.Z.N.A. ${ }^{\circledR}$ Soil DNA kit (Omega Bio-Tec, Inc., USA) according to the manufacturer's instructions. The DNA extracts were stored at $-20^{\circ} \mathrm{C}$ prior to their use in PCR amplifications. The V3-V4 hypervariable regions of $16 \mathrm{~S}$ rRNA were amplified from the microbial genomic DNA using barcoded fusion primers (forward primers: 341 FCCTACACGACG CTCTTCCGATCTNCCTACGGGNGGCWGCAG, reverse primers: $805 \mathrm{R}$ GACTGGAGTTCCTTGGCACCCGAGAATTCCAGACTACHVGGGTATCT

AATCC). For each sample, PCR products were combined from three $50 \mu \mathrm{l}$ reactions, quantified, and the PCR products from each soil sample were combined in equimolar concentrations for paired-end 250 cycle sequencing on the Illumina MiSeq instrument as described by Ding et al. [12]. All sequences were subjected to systematic checks to reduce sequencing and PCR errors. High quality sequence reads (i.e., $>200$ bp in length, quality score of $>25$, exact match to barcode and primer, and containing no ambiguous bases) were retained. Sequences were clustered and assigned to operational taxonomic units (OTUs) at a 3\% dissimilarity level using the Uclust software (uclust v1.1.579). The bacterial diversity is shown by the number of unique OTUs [12]. The raw reads were deposited into the NCBI Sequence Read Archive (SRA) database under accession number SRP076136.

\subsection{Statistical Analysis}

The results were analyzed using SPSS software (version 14.0 for Windows, Chicago, IL, USA). The relative abundance of bacterial genera in the rhizosphere soil between moncropped and intercropped konjac grown for three years were analyzed using one-way analysis of variance (ANOVA; Levene's test was used to assess the equality of variances before performing ANOVA), and significant differences between the means were determined by the LSD test. The differences were considered statistically significant when $\mathrm{P}<0.05$. T-tests were performed with Microsoft Excel, and all p-values were adjusted by False Discovery Rate (FDR) using the $\mathrm{BH}$ method with the mt.rawp2adjp function in $\mathrm{R}$. The substrate utilization pattern, which was based on the Ecoplate data, was analyzed by principal component analysis. A probability level of $\mathrm{P}<0.05$ was used to indicate statistical significance, unless otherwise stated. Additionally, the alpha diversity statistics including Chaol and ACE richness estimator, Shannon diversity index and Simpson diversity index were calculated for each sample.

\section{Results}

\subsection{Properties of Cultivation Soil}

Konjac usually grows in slightly acidic or neutral soil. The most appropriate $\mathrm{pH}$ 
for normal growth of konjac is 6.0 - 7.5. Soil $\mathrm{pH}$ decreased dramatically in the monocrop and remained basically neutral in the intercropped fields over the course of the experiment (three years) (Table 1). The soil $\mathrm{pH}$ was maintained within an acceptable range in the intercropped fields, but the soil $\mathrm{pH}$ of farmland-grown konjac became acidic in years 2 and 3 . The accumulation of phenolic acids ultimately results in a significant decrease in soil $\mathrm{pH}$. The organic matter, available nitrogen, available phosphorus, and available potassium contents in the soil were higher in the third year than in the first two years for the monocrop, while the soil nutrients were generally unchanged under intercropping conditions, which indicating continuous cropping soil nutrient was eutrophication under monocrop and relative balance under intercropping under.

\subsection{The Effect of Intercropping on the Incidence of Soft Rot Disease}

We observed significant differences in disease among the different tillage modes. As shown Figure 2, the disease incidences for soft rot under monocrop and intercropping conditions were $73.1 \%$ and $3.1 \%$, respectively. Compared with the

Table 1. The main physicochemical characteristics of soil samples used for the analysis of bacteria diversity.

\begin{tabular}{cccccc}
\hline $\begin{array}{c}\text { Soil } \\
\text { sample }\end{array}$ & $\mathrm{pH}$ & $\begin{array}{c}\text { Organic matter } \\
\left(\mathrm{g} \cdot \mathrm{kg}^{-1}\right)\end{array}$ & $\begin{array}{c}\text { Available } \\
\mathrm{N}\left(\mathrm{mg} \cdot \mathrm{kg}^{-1}\right)\end{array}$ & $\begin{array}{c}\text { Available } \\
\mathrm{P}\left(\mathrm{mg} \cdot \mathrm{kg}^{-1}\right)\end{array}$ & $\begin{array}{c}\text { Available } \\
\mathrm{K}\left(\mathrm{mg} \cdot \mathrm{kg}^{-1}\right)\end{array}$ \\
\hline F0 & $6.51 \pm 0.01 \mathrm{~d}$ & $3.87 \pm 0.01 \mathrm{a}$ & $69.77 \pm 0.65 \mathrm{c}$ & $7.91 \pm 0.13 \mathrm{f}$ & $157.67 \pm 2.40 \mathrm{~b}$ \\
F1 & $7.32 \pm 0.02 \mathrm{~b}$ & $2.49 \pm 0.01 \mathrm{f}$ & $48.88 \pm 1.17 \mathrm{f}$ & $10.19 \pm 0.60 \mathrm{e}$ & $79.67 \pm 1.20 \mathrm{~d}$ \\
F2 & $5.45 \pm 0.02 \mathrm{~g}$ & $2.62 \pm 0.01 \mathrm{e}$ & $90.42 \pm 1.17 \mathrm{~b}$ & $12.24 \pm 0.39 \mathrm{~d}$ & $70.00 \pm 0.58 \mathrm{e}$ \\
F3 & $5.74 \pm 0.02 \mathrm{f}$ & $3.78 \pm 0.02 \mathrm{~b}$ & $67.78 \pm 2.30 \mathrm{~cd}$ & $46.76 \pm 0.70 \mathrm{a}$ & $173.00 \pm 0.58 \mathrm{a}$ \\
G0 & $6.20 \pm 0.01 \mathrm{e}$ & $2.56 \pm 0.02 \mathrm{ef}$ & $106.63 \pm 0.95 \mathrm{a}$ & $15.19 \pm 0.51 \mathrm{c}$ & $81.00 \pm 3.06 \mathrm{~d}$ \\
G1 & $7.37 \pm 0.02 \mathrm{a}$ & $2.67 \pm 0.03 \mathrm{e}$ & $64.52 \pm 0.82 \mathrm{~d}$ & $15.18 \pm 0.13 \mathrm{c}$ & $92.00 \pm 1.15 \mathrm{c}$ \\
G2 & $7.04 \pm 0.02 \mathrm{c}$ & $3.38 \pm 0.03 \mathrm{c}$ & $56.35 \pm 0.81 \mathrm{e}$ & $16.50 \pm 0.13 \mathrm{~b}$ & $59.67 \pm 0.88 \mathrm{f}$ \\
G3 & $7.14 \pm 0.01 \mathrm{c}$ & $3.19 \pm 0.04 \mathrm{~d}$ & $66.97 \pm 1.57 \mathrm{~cd}$ & $17.75 \pm 0.48 \mathrm{~b}$ & $53.33 \pm 0.67 \mathrm{~g}$ \\
\hline
\end{tabular}

Letters indicate the Shortest Significant ranges (SSR) at $\mathrm{P}=0.05$ for the different treatments. Different letters denote a significant difference at $\mathrm{p}<0.05$.

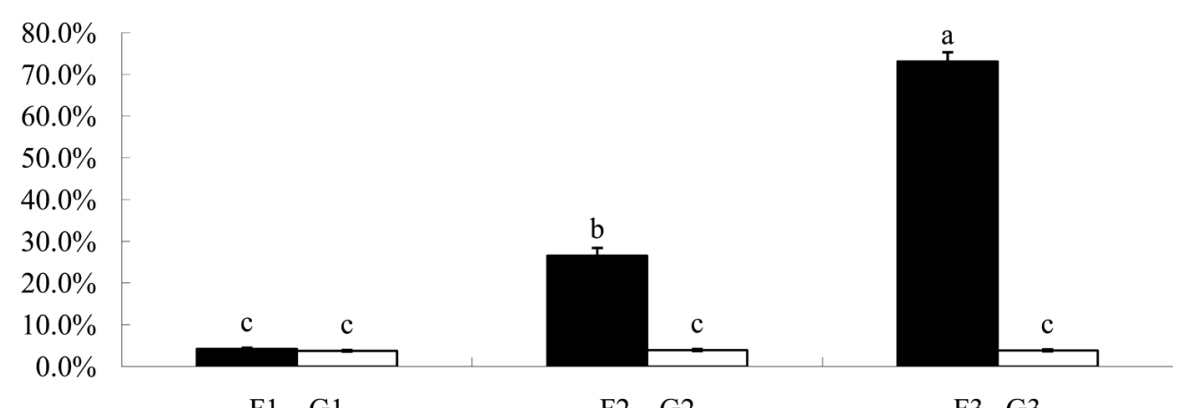

F1 G1

F2 G2

F3 G3

Figure 2. Incidence of soft rot disease under monocrop and intercropped conditions for three years of continuous cropping. Different lowercase letters indicate significant differences $(\mathrm{P}<0.01$; Fisher's LSD test and Duncan's range test). 
konjac plants grown under monocrop conditions, the intercropped plants had almost no detectable soft rot disease. These results show very clearly that the incidence of soft rot disease can be effectively reduced when konjac is grown under economic forest intercropping conditions.

\subsection{General Analyses of the DNA Sequence Data}

Initially, a total of $1,277,396$ reads were generated by sequencing the $16 \mathrm{~S}$ rDNA gene fragments for all samples. After sequence filtering, 1,235,270 high quality sequences (average length of $273 \mathrm{bp}$ ) with a $97 \%$ valid sequence ratio were used for this project. Based on $97 \%$ species similarity, a total of 2617 operational taxonomic units (OTUs) were separately obtained from all samples. Among the OTUs, 400 OTUs ( 15\%) were returned as unclassified. The average length of the sequence clusters was $440 \mathrm{bp}$, and they were classified into different taxonomic groups using uclust [16].

\subsection{Microbial $\alpha$-Diversity}

A total of 1,277,396 paired-end 250-bp reads were acquired from all 24 samples. After initial quality control, 1,235,270 high quality sequences were obtained. With an average of $97,202.6875$ sequence reads per sample (the minimum number from one sample was 117,323 and the maximum was 191,931) and used for this project. The average length of the sequence reads was $440 \mathrm{bp}$, and they were classified into different taxonomies using UCLUST software.

Moreover, the alpha diversity indices including richness (Chao 1 and ACE) and diversity (Shannon and Simpson) are shown in Table 2. For the monocrop rhizosphere soil, the Chao 1, ACE, Shannon, and Simpson indices showed significantly lower for G3. Compared with the field rhizosphere soil, the intercropped rhizosphere soil F2 is very low.

\subsection{Microbial $\beta$-Diversity}

The $\beta$-diversity was estimated using the unweighted UniFrac distance metrics. The principal coordinate analysis ( $\mathrm{PCoA})$, which is based on the weighted

Table 2. Bacterial $\alpha$-diversity indices

\begin{tabular}{ccccc}
\hline & Chao1 & ACE & Shannon & Simpson \\
\hline G0 & $2222.53 \pm 14.70 \mathrm{~b}$ & $2191.70 \pm 15.33 \mathrm{c}$ & $9.49 \pm 0.02 \mathrm{~b}$ & $0.9961 \pm 0.00020 \mathrm{~d}$ \\
G1 & $2198.98 \pm 57.52 \mathrm{~b}$ & $2174.50 \pm 55.89 \mathrm{c}$ & $9.57 \pm 0.05 \mathrm{ab}$ & $0.9969 \pm 0.00011 \mathrm{ab}$ \\
G2 & $2372.95 \pm 1.85 \mathrm{a}$ & $2326.21 \pm 1.85 \mathrm{ab}$ & $9.50 \pm 0.04 \mathrm{~b}$ & $0.9967 \pm 0.00008 \mathrm{bc}$ \\
G3 & $1960.88 \pm 60.35 \mathrm{c}$ & $1924.22 \pm 50.99 \mathrm{~d}$ & $9.34 \pm 0.02 \mathrm{c}$ & $0.9965 \pm 0.000002 \mathrm{~cd}$ \\
F0 & $2315.90 \pm 43.38 \mathrm{ab}$ & $2299.51 \pm 49.84 \mathrm{~b}$ & $9.61 \pm 0.05 \mathrm{ab}$ & $0.9969 \pm 0.00005 \mathrm{ab}$ \\
F1 & $2444.07 \pm 19.27 \mathrm{a}$ & $2420.26 \pm 15.51 \mathrm{a}$ & $9.70 \pm 0.05 \mathrm{a}$ & $0.9971 \pm 0.00008 \mathrm{ab}$ \\
F2 & $1941.03 \pm 63.24 \mathrm{c}$ & $1881.54 \pm 34.36 \mathrm{~d}$ & $8.98 \pm 0.02 \mathrm{~d}$ & $0.9955 \pm 0.00003 \mathrm{e}$ \\
F3 & $2420.44 \pm 6.07 \mathrm{a}$ & $2370.01 \pm 8.25 \mathrm{ab}$ & $9.68 \pm 0.06 \mathrm{a}$ & $0.9971 \pm 0.00027 \mathrm{a}$ \\
\hline
\end{tabular}


UniFrac distances of the $16 \mathrm{~S}$ rRNA sequences, was performed to cluster bacteria populations from the soil samples from $0,1,2$, and 3 years of continuous cropping in the different farming modes (Figure 3 ). The first two factors accounted for $48.4 \%$ and $11.7 \%$ of the variation. The bacteria community of each soil sample was separated by number of cropping years in the monocrop, but the bacteria communities were not well separated in the intercropped soil samples (Figure 3). These results demonstrate that the bacteria communities of the soil monocrop samples changed significantly with increasing years of continuous cropping, while the intercropped samples did not appear to show the same changes, except possibly for the soil sample from year 3 .

\subsection{Bacterial Community Composition}

Comparisons of the relative abundance of the top 43 classified bacterial genera (relative abundance $>0.3 \%$ ) showed significant variations among the rhizosphere soils (Figure 4). The predominant genera were Gemmata $(16.25 \%<$ relative abundance $<24.55 \%)$, Aquicella $(4.36 \%<$ relative abundance $<12.11 \%)$, and Planctomyces $(4.65 \%<$ relative abundance $<7.73 \%)$ across all samples. With increasing years of continuous cropping, Candidatus, Koribacter, Lactobacillus, Pirellula, Achromobacter, Chitinophaga, Spirochaeta, Sphingomonas, Akkermansia, Fimbriimonas, Rothia, and Luteolibacter increased under monocropping conditions, but decreased for the intercropped planting, while Paenibacillus, Afifella, and Sphingobium decreased for the monocrop but increased for the intercrop.

There were 11 out of the 43 classified bacterial genera that were related to the duration of continuous cropping in the two different planting modes (Table 3 ). The relative abundance of Pirellula, Achromobacter, Chitinophaga, Sphingomonas, Rothia, Nocardia, Asticcacaulis, Deinococcus, and Catellatospora were significantly affected by planting age and mode; Pseudomonas was significantly

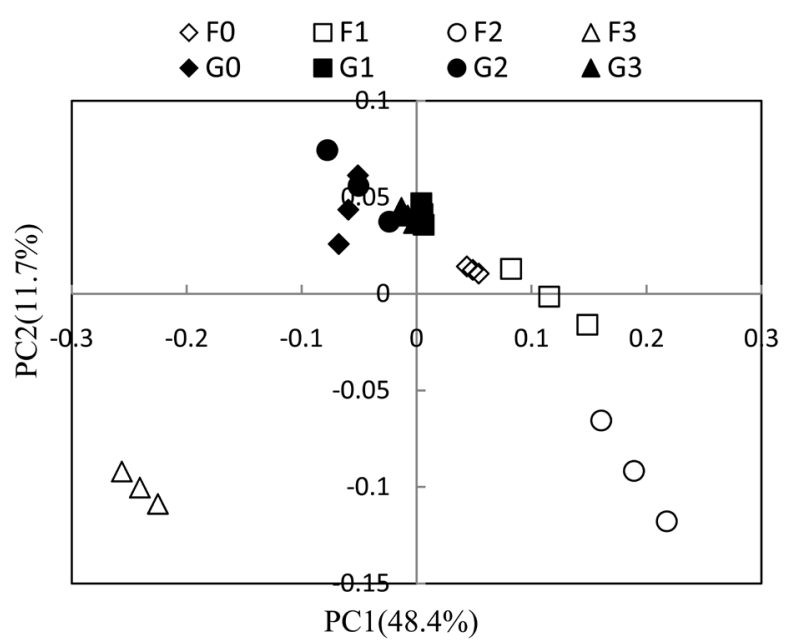

Figure 3. PCoA of unweighted UniFrac distances for the rhizosphere soil bacteria of the two farming modes for three years of continuously-cropped konjac. 


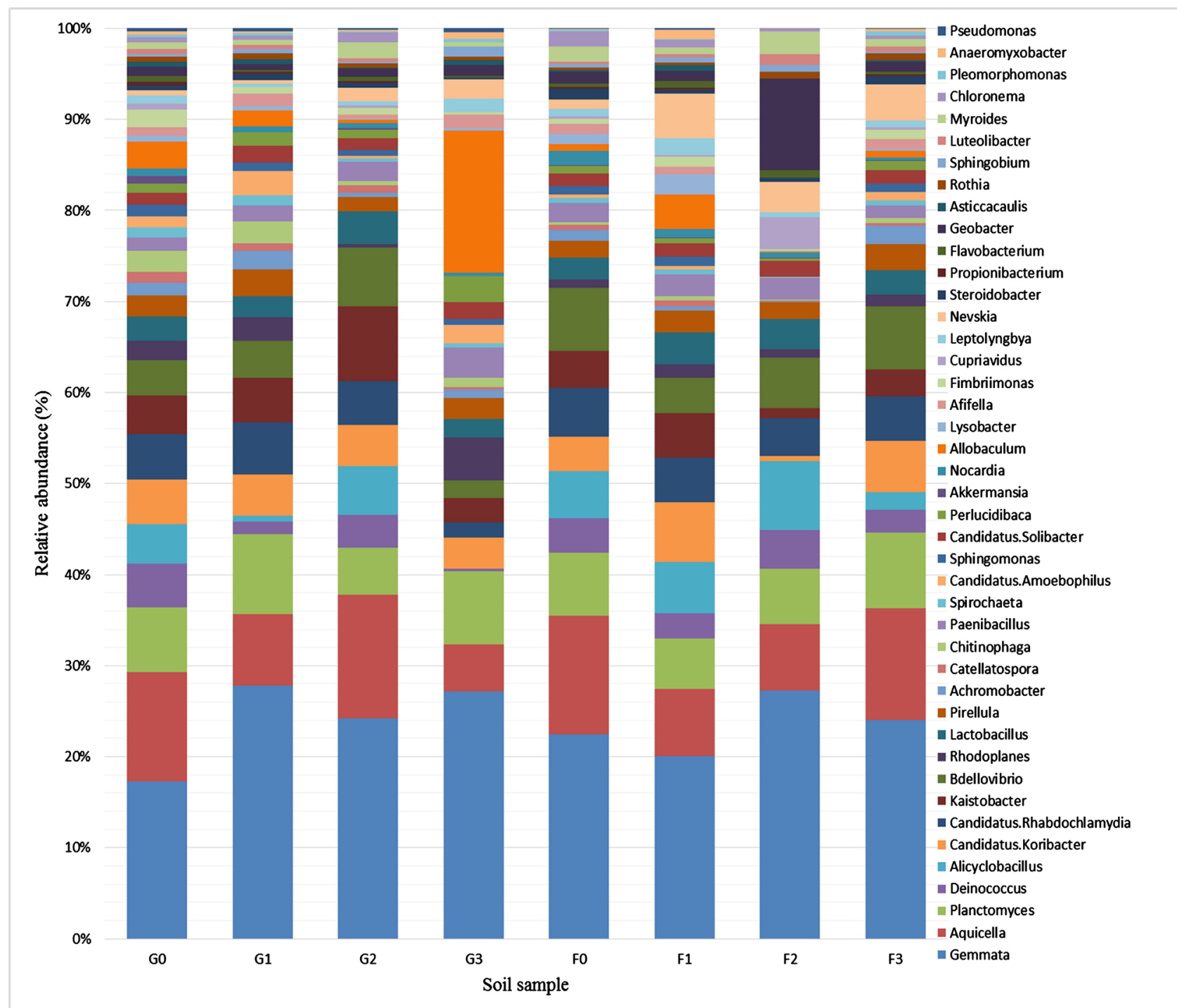

Figure 4. Relative abundance of bacterial genera in the rhizosphere soil of monocropped and intercropped konjac grown continuously for three years. Relative abundances are based on the proportional frequencies of DNA sequences that could be classified.

Table 3. Analysis of variance (ANOVA) of the relative abundance of bacterial genera in the rhizosphere soil between moncropped and intercropped konjac grown for three years.

\begin{tabular}{|c|c|c|c|c|c|c|}
\hline Factor & Pirellula & Achromobacter & Chitinophaga & Sphingomonas & Myroides & Rothia \\
\hline M & 0.65 & 0.60 & 0.07 & 0.48 & 0.05 & 0.97 \\
\hline $\mathrm{Y}$ & 0.13 & 0.47 & 0.38 & 0.23 & $0.02^{*}$ & 0.78 \\
\hline $\mathrm{M} * \mathrm{Y}$ & $0.03^{*}$ & $0.01^{*}$ & $0.01^{*}$ & $0.01^{*}$ & 0.66 & $0.02^{\star}$ \\
\hline Factor & Nocardia & Asticcacaulis & Pseudomonas & Deinococcus & Catellatospora & \\
\hline M & 0.37 & 0.11 & $0.03^{*}$ & 0.42 & 0.13 & \\
\hline $\mathrm{Y}$ & 0.17 & 0.07 & 0.28 & 0.17 & 0.33 & \\
\hline$M^{\star} \mathrm{Y}$ & $0.02^{*}$ & $0.01^{*}$ & 0.21 & $0.03^{*}$ & $0.01^{\star}$ & \\
\hline
\end{tabular}

Note: M: monocrop and intercrop; Y: Years; ${ }^{\star}$ Same letters indicates no significant difference, different letters mean significant difference. 
affected by the planting mode; and Myroides was significantly affected by planting age.

As shown in Table 4, the abundance of Staphylococcus, Anaeromyxobacter, and Alicyclobacillus in the monocrop, and Luteolibacter, Oscillospira, Opitutus, Candidatus, Rhabdochlamydia, Devosia, Asteroleplasma, Corynebacterium, Bdellovibrio, and Streptococcus in the intercroppped soils were significantly different $(P<0.05)$ with respect to the duration of continuous cropping. Luteolibacter,

Table 4. Comparisons (T-test) of the relative abundances of bacterial genera between cropping years and the two different cultivation modes in konjac field soils.

\begin{tabular}{|c|c|c|}
\hline Genus & $\begin{array}{l}\text { Relative fold-change } \\
\text { F3/F0 }\end{array}$ & $p$ value $\left({ }^{*} \mathrm{p}<0.05\right)$ \\
\hline Staphylococcus & 0.00 & $0.013^{*}$ \\
\hline Anaeromyxobacter & 4.44 & $0.017^{\star}$ \\
\hline Alicyclobacillus & 0.37 & $0.020^{*}$ \\
\hline Genus & $\begin{array}{l}\text { Relative fold-change } \\
\text { G3/G0 }\end{array}$ & $p$ value $\left({ }^{*} \mathrm{p}<0.05,{ }^{* *} \mathrm{p}<0.01\right)$ \\
\hline Luteolibacter & 0.03 & $0.004^{\star *}$ \\
\hline Oscillospira & 8360000.00 & $0.011^{\star}$ \\
\hline Opitutus & 11.12 & $0.015^{\star}$ \\
\hline Candidatus, Rhabdochlamydia & 0.30 & $0.018^{*}$ \\
\hline Devosia & 32120000.00 & $0.026^{*}$ \\
\hline Asteroleplasma & 7.90 & $0.029^{*}$ \\
\hline Corynebacterium & 2.17 & $0.033^{\star}$ \\
\hline Bdellovibrio & 0.44 & $0.040^{*}$ \\
\hline Streptococcus & 0.00 & $0.044^{\star}$ \\
\hline Genus & $\begin{array}{c}\text { Relative fold-change } \\
\text { F3/G3 }\end{array}$ & $p$ value $\left({ }^{*} \mathrm{p}<0.05,{ }^{* *} \mathrm{p}<0.01\right)$ \\
\hline Luteolibacter & 0.03 & $0.003^{* *}$ \\
\hline Opitutus & 15.56 & $0.010^{*}$ \\
\hline Lentzea & 3.31 & $0.014^{\star}$ \\
\hline Allobaculum & 19.78 & $0.017^{*}$ \\
\hline Corynebacterium & 5.89 & $0.021^{\star}$ \\
\hline Patulibacter & 1.26 & $0.024^{*}$ \\
\hline Asteroleplasma & 8.81 & $0.028^{*}$ \\
\hline Leptolyngbya & 1.92 & $0.032^{*}$ \\
\hline Spirosoma & 0.11 & $0.035^{\star}$ \\
\hline Aquicella & 0.40 & $0.038^{\star}$ \\
\hline Paenibacillus & 2.35 & $0.042^{*}$ \\
\hline Nitrosopumilus & 0.10 & $0.045^{\star}$ \\
\hline
\end{tabular}

Note: ${ }^{\star}$ Same letters indicates no significant difference, different letters mean significant difference. 
Opitutus, Lentzea, Allobaculum, Corynebacterium, Patulibacter, Asteroleplasma, Leptolyngbya, Spirosoma, Aquicella, Paenibacillus, and Nitrosopumilus were significantly different $(P<0.05)$ between the two planting modes. The differences in Luteolibacter were highly significant $(P<0.01)$, and Opitutus, Asteroleplasma and Corynebacterium differed significantly $(P<0.05)$ in the G3/G0 and F3/G3 soil sample comparisons.

\section{Discussion}

Intercropping, the simultaneous cultivation of more than a single crop species, has been used throughout history and remains common among farmers of small landholdings in mountainous areas. One benefit of this practice may be disease control. In phenomenological research comparing disease in monocrops and intercrops, primarily due to foliar fungi, intercropping reduced disease incidence by $73 \%$ in $>200$ studies [17]. Tree-crop intercropping systems are the combined culture of trees and arable crops on the same land management unit. The integration of trees into cropping systems increases the soil organic matter content due to the additional deposition of tree leaves and the turnover of fine roots [18], which may help to improve soil bacteria activity and nutrient cycling rates [19] [20]. The importance of the rhizosphere bacteria for plant growth and health is widely acknowledged [21].

At present, cultivation models have been actively promoted for konjaceconomic forest intercropping in many parts of China, because this strategy can ensure good growth and a high yield of konjac, which is closely related to soil nutrients and microflora, which was studied by the dilution method [22]. But $1 \mathrm{~g}$ of soil may contain $>10^{9}$ bacterial cells and $>40,000$ bacterial genomes [23], so the species richness and evenness may not be ecologically relevant in the microbial world. The Illumina sequencing method used in this study overcame this limitation, and allowed us to obtain thousands of sequences simultaneously so that we could identify as many microorganisms as possible, which enabled systematic comparisons of the bacterial communities from both monocrop and intercropped rhizosphere soils, and also helps us to better understand the microecological changes that accompany soft rot disease of $A$. konjac. In our research, we used Illumina MiSeq high-throughput DNA sequencing to show that the rhizosphere soil bacteria communities changed significantly during three years of continuous cropping in the monocrop, but showed almost no change under intercropping conditions. Chao1, ACE, Shannon index and Simpson index are commonly used to characterize the diversity of soil bacterial, and can reveal the differences of soil bacterial species and function [24]. Chaol or ACE was greater, the community richness was greater. Shannon index was greater, the community diversity was greater, but Simpson index was greater, the community diversity was lower [25]. Comparing with monocropping, the intercropping significantly improves rhizosphere soil bacterial Shannon diversity index and richness index [26] [27]. In our study, Chaol, ACE, Shannon index and 
Simpson index were higher in konjac-sumac intercropping systems than that obtained under monocropping in general (Table 2).

The microecology of healthy growth and higher yield in Amorphophallus konjac was previously studied in farmland and under acacia forest. The results showed that certain beneficial bacteria were predominant, there were fewer harmful bacteria in the rhizosphere and rhizoplane soils of $A$. konjac grown under acacia forest, and that the soil also had a higher organic matter content [28]. In our reasearch, the genus Pseudomonas was significantly affected by the different cultivation modes. Pseudomonas contains has many beneficial bacterial species that can be used to control root diseases of vegetables and fruits [29] and the tuber-rotting disease of Jerusalem artichoke [30]. The disease incidence under monocrop and intercropping conditions was $73.1 \%$ and $3.1 \%$ in the third year of continuous cropping, respectively (Figure 2). Myroides was significantly affected by planting age. Some species of Myroides have been shown to have antagonistic activity against the oomycete pathogen Phytophthora nicotianae [31] and the fungal pathogen Alternaria alternata [32]. Thus, species of Pseudomonas and Myroides may play important roles in reducing the incidence of soft rot disease in continuous plantings under different farming modes. This could have shown if the bacteria in Konjac come from the intercropping plant or if the intercropping is changing the soil physicochemistry and is therefore changing the community structure.

Simon et al. [33] showed that tree-based intercropping systems provide a more heterogeneous vegetation cover and, by implication, a patchier distribution of leaf litter and rooting patterns that can affect the chemical and nutritional properties of soil. Similarly, we found that soil $\mathrm{pH}$ and organic matter content decreased generally in the monocrop and remained basically unchanged in the intercrop over the 3-year duration of the experiment (Table 1). This could be due to the monocrop conditions causing changes in the bacterial species and the quantity of plant root exudates. Phenolic compounds, ferulic acid, hydrocyanic acid, and benzoic acid in plant root exudates has been shown to have serious effects on soil $\mathrm{pH}$ and on rhizosphere microorganisms [34]. Higher microbial population stability was also found in the tree-based intercropped planting than in the conventional monocropping system at the St-Rémi site by Simon et al. [33]. We observed that the alpha diversity indices were relatively stable under intercropping, changed significantly in the monocrop during the three years of continuous cropping (Table 2). These results were in agreement with previous studies showing that continuous cultivataion under monocrop conditions can decrease soil bacterial diversity in the rhizosphere of tomato [35] and watermelon [36] as shown by the use of PCR-DGGE, quantitative real-time PCR, and next-generation sequencing.

The relative abundances of bacterial genera Luteolibacter and Bacteroides showed a highly significant difference between the moncrop and the intercrop for three continuous years, while Opitutus, Lentzea, Allobaculum, Corynebacte- 
rium, Patulibacter, Asteroleplasma, Leptolyngbya, Spirosoma, Aquicella, Paenibacillus, and Nitrosopumilus were significantly different. This could have shown if the bacteria in Konjac come from the intercropping plant or if the intercropping is changing the soil physicochemistry and is therefore changing the community structure.

The purpose of this study was to develop optimal conditions for cultivating konjac to allow the plants to express their full production potential, and to limit soft rot disease pressure. One major objective is to initiate a biocontrol program to reduce the incidence of serious soft rot disease in A. konjac, and understanding the bacteria community structure at the genus level provided useful information for screening and identification of bacterial disease antagonists.

\section{Acknowledgements}

The work was financially supported by grants from the Nature Science Foundation of China [grant number 31401706] and the National Spark Program [grant number 2015GA760002].

\section{Conflicts of Interest}

The authors declare no conflicts of interest.

\section{References}

[1] Vasques, C.A., Rossetto, S., Halmenschlager, G., Linden, R., Heckler, E., Poblador Fernandez, M.S. and Lancho Alonso, J.L. (2008) Evaluation of the Pharmacotherapeutic Efficacy of Garcinia cambogia plus Amorphophallus konjac for the Treatment of Obesity. Phytotherapy Research, 22, 1135-1140.

https://doi.org/10.1002/ptr.2323

[2] Mayo, S.J., Bogner, J. and Boyce, P.C. (1997) The Genera of Araceae. Royal Botanic Gardens, Kew.

[3] Cui, M., Zhao, X.X., Xie, L.H., Zheng, Y.H., Qiu, Y.G. and Liu, H.P. (2001) Hazard Investigation and Occurrence of Amorphophallus konjac Disease in Ankang Region. Shaanxi Agricultural Science, 42, 42-44.

[4] Liu, L.P., Zheng, M., Zou, A., et al (2012) Effect of Intercropping Pattern on Disease and Yield of Amorphophallus konjac. Forest By-Product and Specialty in China, 5, 58-59. (in Chinese)

[5] He, J., Wei, L.Y. and Zhou, L.J. (2012) Effect of Intercropping Pattern and Woodland Type on Konjac Disease and Yield. Shaanxi Forestry Technology, 3, 37-38, 41. (in Chinese)

[6] Zhang, Z.L., Liu, L.P. and Zheng, M. (2012) Cultivation Techniques of Amorphophallus rivieri under Robinia pseudoacacia Forest. Northern Horticulture, 13, 148-150. (in Chinese)

[7] Wieland, G., Neumann, R. and Backhaus, H. (2001) Variation of Microbial Communities in Soil, Rhizosphere, and Rhizoplane in Response to Crop Species, Soil Type, and Crop Development. Applied and Environmental Microbiology, 67, 5849-5854. https://doi.org/10.1128/AEM.67.12.5849-5854.2001

[8] Hamel, C., Vujanovic, V., Jeannotte, R., et al (2005) Negative Feedback on a Peren- 
nial Crop: Fusarium Crown and Root Rot of Asparagus Is Related to Changes in Soil Microbial Community Structure. Plant and Soil, 268, 75-87. https://doi.org/10.1007/s11104-004-0228-1

[9] Schmidt, P.A., Bálint, M., Greshake, B., Bandow, C., Römbke, J. and Schmitt, I. (2013) Illumina Metabarcoding of a Soil Fungal Community. Soil Biology and Biochemistry, 65, 128-132. https://doi.org/10.1016/j.soilbio.2013.05.014

[10] Tago, K., Itoh, H., Kikuchi, Y., Hori, T., Sato, Y., Nagayama, A., et al (2014) A Fine-Scale Phylogenetic Analysis of Free-Living Burkholderia Species in Sugarcane Field Soil. Microbes and Environments, 29, 434-437. https://doi.org/10.1264/jsme2.ME14122

[11] Wu, J.P., Diao, Y., Gu, Y.C. and Hu, Z.L. (2010) Infection Pathways of Soft Rot Pathogens on Amorphophallus konjac. African Journal of Microbiology Research, 4, 1495-1499.

[12] Ding, Z.L., Wu, J.P., You, A.Q., Huang, B.Q. and Cao, C.G. (2017) Effects of Heavy Metals on Soil Microbial Community Structure and Diversity in the Rice (Oryza sativa L. subsp. Japonica, Food Crops Institute of Jiangsu Academy of Agricultural Sciences) Rhizosphere. Soil Science and Plant Nutrition, 1, 1-9.

https://doi.org/10.1080/00380768.2017.1381572

[13] Kowalchuk, G.A., Stienstra, A.W., Heilig, G.H.J., Stephen, J.R. and Woldendorp, J.W. (2000) Molecular Analysis of Ammonia-Oxidising Bacteria in Soil of Successional Grasslands of the Drentsche A (The Netherlands). FEMS Microbiology Ecology, 31, 207-215. https://doi.org/10.1111/j.1574-6941.2000.tb00685.x

[14] İnceoğlu, Ö., Hoogwout, E.F., Hill, P. and van Elsas, J.D. (2010) Effect of DNA Extraction Method on the Apparent Microbial Diversity of Soil. Applied and Environmental Microbiology, 76, 3378-3382. https://doi.org/10.1128/AEM.02715-09

[15] Fei, F.H., Zhang, H.M., Peng, J.B., Liao, W.Y. and Xu, X.Y. (2010) Study on Konjac Agronomic Traits and Disease and Freezing Investigation Criteria and Evaluation Method. Modern Agricultural Technology, 21, 183-184.

[16] Edgar, R.C. (2010) Search and Clustering Orders of Magnitude Faster than BLAST. Bioinformatics, 26, 2460-2461. https://doi.org/10.1093/bioinformatics/btq461

[17] Mark, A. (2013) Boudreau, Diseases in Intercropping Systems. Annual Review of Phytopathology, 51, 499-519. https://doi.org/10.1146/annurev-phyto-082712-102246

[18] Peichl, M., Thevathasan, N.V., Gordon, A.M., Huss, J. and Abohassan, R.A. (2006) Carbon Sequestration Potentials in Temperate Tree-Based Intercropping Systems, Southern Ontario, Canada. Agroforestry Systems, 66, 243-257. https://doi.org/10.1007/s10457-005-0361-8

[19] Jose, S., Gillespie, A.R., Seifert, J.R., Mengel, D.B. and Pope, P.E. (2000) Defining Competition Vectors in a Temperate Alley Cropping System in the Midwestern USA. 3. Competition for Nitrogen and Litter Decomposition Dynamics. Agroforestry Systems, 48, 61-77. https://doi.org/10.1023/A:1006241406462

[20] Mungai, N.W., Motavalli, P.P., Kremer, R.J. and Nelson, K.A. (2005) Spatial Variation of Soil Enzyme Activities and Microbial Functional Diversity in Temperate Alley Cropping Systems. Biology and Fertility of Soils, 42, 129-136. https://doi.org/10.1007/s00374-005-0005-1

[21] Berg, G. and Smalla, K. (2009) Plant Species and Soil Type Cooperatively Shape the Structure and Function of Microbial Communities in the Rhizosphere. FEMS Microbiology Ecology, 68, 1-13. https://doi.org/10.1111/j.1574-6941.2009.00654.x 
[22] He, F., Xue, H., Zhang, Z.L. and Duan, J.L. (2014) Microbial Ecological Study about Amorphophallus konjac Root-Zone Soil under Walnut Grove. Journal of Beijing Union University, 28, 26-32.

[23] Torsvik, V., Goksoyr, J. and Daae, F.L. (1990) High Diversity in DNA of Soil Bacteria. Applied and Environmental Microbiology, 56, 782-787.

[24] Tian, C.J., Chen, J.K. and Zhong, Y. (2003) Phylogentic Diversity of Microbes and Its Perspectives in Conservation Biology. Chinese Journal of Applied Ecology, 14, 609-612.

[25] Pitta, D.W., Pinchak, E., Dowd, S.E., Osterstock, J., Gontcharova, V., Youn, E., Dorton, K., Yoon, I., Min, B.R., Fulford, J.D., et al. (2010) Rumen Bacterial Diversity Dynamics Associated with Changing from Bermudagrass Hay to Grazed Winter Wheat Diets. Microbial Ecology, 59, 511-522. https://doi.org/10.1007/s00248-009-9609-6

[26] Nai, F.J., Wu, L.H., Liu, H.Y., Ren, J., Liu, W.X. and Luo, Y.M. (2013) Effects of Intercropping Sedum plumbizincicola and Apium graceolens on the Soil Chemical and Microbiological Properties under the Contamination of Zinc and Cadmium from Sewage Sludge Application. Chinese Journal of Applied Ecology, 24, 1428-1434.

[27] Kihara, J., Martius, C., Bationo, A., Thuita, M., Lesueur, D., Herrmann, L., Amelung, W. and Vlek, P.L.G. (2012) Soil Aggregation and Total Diversity of Bacteria and Fungi in Various Tillage Systems of Sub-Humid and Semi-Arid Kenya. Applied Soil Ecology, 58, 12-20. https://doi.org/10.1016/j.apsoil.2012.03.004

[28] He, F., Zhang, Z.L., Liu, L., Cui, M. and Xue, Q.H. (2015) Microecological Mechanism for Healthy Growth and Higher Yield of Amorphophallus konjac under Acacia Forest. Acta Botanica Boreali-Occidentalia Sinica, 35, 364-372.

[29] Anjaiah, V. (2004) Biological Control Mechanisms of Fluorescent pseudomonas Species Involved in Control of Root Diseases of Vegetables/Fruits, Fruit and Vegetable Diseases. Springer, Berlin, 453-500.

[30] Jin, S.Z., Liu, L., Liu, Z., Long, X.H., Shao, H.B. and Chen, J.Y. (2013) Characterization of Marine Pseudomonas spp. Antagonist towards Three Tuber-Rotting Fungi from Jerusalem Artichoke, a New Industrial Crop. Industrial Crops and Products, 43, 556-561. https://doi.org/10.1016/j.indcrop.2012.07.038

[31] Jin, F.L. (2011) Genetic Diversity and Phylogeny of Antagonistic Bacteria Isolated from Tobacco Rhizosphere. Shandong Agricultural University, Taian.

[32] You, C., Zhang, C., Feng, C., Wang, J. and Kong, F. (2015) Myroides odoratimimus, a Biocontrol Agent from the Rhizosphere of Tobacco with Potential to Control Alternaria alternate. BioControl, 60, 555-564. https://doi.org/10.1007/s10526-015-9654-7

[33] Simon, L., Robert, L.B., Chantal, H. and Carole, B. (2009) Do Tree-Based Intercropping Systems Increase the Diversity and Stability of Soil Microbial Communities? Agriculture. Ecosystems and Environment, 131, 25-31. https://doi.org/10.1016/j.agee.2008.08.010

[34] Zhang, S.X. and Gao, Z.Q. (2000) Continuous Cropping Obstacle and Rhizospheric Micro-Ecology II. Root Exudates and Phenolic Acids. Chinese Journal of Applied Ecology, 11, 152-156.

[35] Ma, N.N. and Li, T.L. (2013) Effect of Long-Term Continuous Cropping of Protected Tomato on Soil Microbial Community Structure and Diversity. Acta Horticulturae Sinica, 40, 255-264. 
[36] Ling, N., Deng, K.Y., Song, Y., Wu, Y.C., Zhao, J., Raza, W., Huang, Q.W. and Shen, Q.R. (2014) Variation of Rhizosphere Bacterial Community in Watermelon Continuous Mono-Cropping Soil by Long-Term Application of a Novel Bioorganic Fertilizer. Microbiological Research, 169, 570-578.

https://doi.org/10.1016/j.micres.2013.10.004 